\title{
Peranan Sumber Daya terhadap SDM Peternak dan Pengembangan Usaha Ternak Sapi Perah di Kawasan Peternakan Sapi Perah Nasional (KPSPN)
}

\section{The Role of Farmer Resources to the Human Resources and Farming Business Development of Dairy Cattle in the Kawasan Peternakan Sapi Perah Nasional (KPSPN)}

\author{
Amam $^{1 *}$ dan Soetriono ${ }^{2}$ \\ ${ }^{1}$ Program Studi Peternakan, Fakultas Pertanian, Universitas Jember - Indonesia \\ ${ }^{2}$ Program Studi Agribisnis, Fakultas Pertanian, Universitas Jember - Indonesia \\ *Corresponding E-mail: amam.faperta@unej.ac.id \\ (Diterima: 21 Juli 2019; Disetujui: 26 Oktober 2019)
}

\begin{abstract}
ABSTRAK
Sumber daya finansial, teknologi, dan fisik merupakan bagian dari sumber daya internal usaha ternak. Penelitian bertujuan untuk mengevaluasi sumber daya internal usaha ternak sapi perah dan mengkaji pengaruhnya terhadap SDM peternak dan pengembangan usaha ternak. Penelitian dilakukan di Kawasan Peternakan Sapi Perah Nasional (KPSPN) Kabupaten Malang, Jawa Timur. Narasumber penelitian ialah peternak sapi perah anggota Kelompok Usaha Bersama (KUB) Tirtasari Kresna Gemilang. Jumlah responden adalah 174 peternak sapi perah. Pengumpulan data menggunakan metode observasi dan survai dengan menggunakan pengisian kuisioner dan wawancara. Analisis data menggunakan metode Partial Least Square (PLS). Hasil penelitian menunjukkan bahwa 18,9\% SDM peternak dipengaruhi oleh sumber daya internal, sedangkan 55,5\% pengembangan usaha dipengaruhi oleh sumber daya internal dan SDM peternak. Kesimpulan penelitian yaitu sumber daya internal berpengaruh terhadap SDM peternak dan pengembangan usaha ternak.
\end{abstract}

Kata kunci: pengembangan usaha ternak, sapi perah, SDM, sumber daya

\section{ABSTRACT}

Internal resources consist of financial resources, technological resources, and physical resources. The research aims to evaluate the internal resources of dairy cattle farming business and their influence on former human resources and livestock farming business development. The research was carried out in the Kawasan Peternakan Sapi Perah Nasional (KPSPN) of Malang District, East Java. Respondents are dairy farmers who are members of the farmer's institution of Kelompok Usaha Bersama (KUB) Tirtasari Kresna Gemilang. The number of respondents is 174 dairy farmers. Data collection uses observation and survey methods using questionnaires and interviews. Data were analyzed by the PLS (Partial Least Square) method. The results showed that $18.9 \%$ of farmer human resources were influenced by internal resources, while $55.5 \%$ of business development was influenced by internal resources and farmer human resources. The conclusion of the research is that internal resources affect farmer human resources and livestock farming business development.

Keywords: ddairy cattle, farming business development, human resources, resources

\section{PENDAHULUAN}

Kabupaten Malang merupakan salah satu Kawasan Peternakan Sapi Perah Nasional berdasarkan Surat Keputusan Menteri Pertanian Republik Indonesia Nomor
43 tahun 2015 tentang Penerapan Kawasan Sapi Potong, Kerbau, Kambing, Domba, dan Babi Nasional. Salah satu isi dari Keputusan Menteri Pertanian tersebut ialah perencanaan pembangunan kawasan mencakup penyediaan prasarana, sarana penunjang, teknologi, 
pembiayaan, pengelolahan, pemasaran, serta kelembagaan dan sumber daya manusia pengelolanya.

Pengembangan usaha ternak sapi perah didukung oleh berbagai macam sumber daya, salah satunya ialah sumber daya internal. Syukur et al. (2014) menjelaskan bahwa sumber daya internal meliputi sumber daya finansial, teknologi, dan fisik. Amam et al. (2019c) menyatakan bahwa sumber daya yang dapat diakses peternak memiliki peranan penting untuk pengembangan usaha ternak.

Pengembangan usaha ternak sapi perah di Kabupaten Malang sangat memungkinkan untuk dilakukan mengingat Kabupaten Malang merupakan salah satu Kawasan Peternakan Sapi Perah Nasional (KPSPN) dengan daya dukung kelembagaan peternak. Salah satu kelembagaan peternak sapi perah yang terbentuk ialah Kelompok Usaha Bersama (KUB) Tirtasari Kresna Gemilang yang memiliki anggota sebanyak 174 orang. Amam dan Soetriono (2019) mengungkapkan bahwa peranan kelembagaan peternakan selain berfungsi sebagai tindakan preventif untuk mengurangi risiko bisnis juga berfungsi dalam pengembangan usaha ternak untuk mensejahterakan anggotanya.

KUB Tirtasari Kresna Gemilang adalah salah satu kelembagaan peternak sapi perah yang dibentuk pada tahun 2017 dan sudah mempunyai legalitas serta berbadan hukum Nomor 0010084-AH.01.07. Sekretariat KUB Tirtasari Kresna Gemilang berada di Desa Ngabab, Kecamatan Pujon. KUB Tirtasari Kresna Gemilang mempunyai peranan penting untuk peternak sapi perah sebagai kelembagaan. Kelembagaan peternak dapat meningkatkan daya tawar peternak (Nasrul, 2012). Amam dan Harsita (2019a) mengungkapkan bahwa SDM peternak secara positif dipengaruhi oleh performa kelembagaan.

Tujuan penelitian ialah untuk mengevaluasi sumber daya internal peternak sapi perah di Kawasan Peternakan Sapi Perah Nasional (KPSPN) serta mengkaji pengaruhnya terhadap SDM peternak dan pengembangan usaha ternak sapi perah. Sumber daya internal yang dikaji dalam penelitian ini meliputi sumber daya finansial, sumber daya teknologi, dan sumber daya fisik.

\section{METODE}

Pengambilan data dilaksanakan bulan Maret-Juni 2019. Narasumber adalah peternak sapi perah anggota KUB Tirtasari Kresna Gemilang yang terdiri dari 174 orang (total sampling). Penelitian ini menggunakan pendekatan expost facto research dengan metode pengumpulan data yang terdiri dari pengisian kuisioner, wawancara, dan observasi. Kuisioner yang digunakan dalam penelitian berskala likert +1 hingga +5 , sedangkan metode wawancara dan observasi digunakan untuk mendapatkan informasi tambahan dari peternak secara langsung. Analisis data penelitian yang digunakan ialah metode Partial Least Square (PLS). Manfaat penggunaan SmartPLS dalam teknik SEM (Structural Equation Model) ialah untuk menguji teori yang lemah atau menemukan teori yang baru (Wiyono, 2011).

Variabel penelitian meliputi sumber daya finansial, teknologi, fisik, SDM peternak, dan pengembangan usaha ternak. Amam et al. (2019b) menyebutkan bahwa sumber daya finansial merupakan sumber daya yang berhubungan dengan modal atau aset keuangan. Sumber daya teknologi merupakan sumber daya yang berhubungan dengan adopsi, inovasi, dan implikasi pemanfaatan teknologi. Sumber daya fisik merupakan sumber daya yang berhubungan dengan sarana dan prasarana yang mendukung usaha ternak. Indikator dan variabel tersebut ditunjukkan pada Tabel 1.

\section{HASIL DAN PEMBAHASAN}

\section{Sumber Daya Finansial}

Sumber daya finansial merupakan sumber daya yang berhubungan dengan 
Tabel 1. Variabel dan indikator penelitian

\begin{tabular}{|c|c|c|}
\hline Variabel & Indikator & Pengukuran \\
\hline $\begin{array}{l}\text { Sumber daya } \\
\text { finansial }\left(\mathrm{X}_{1}\right)\end{array}$ & $\begin{array}{l}\text { 1. pendapatan utama }\left(\mathrm{X}_{1.1}\right) \\
\text { 2. pendapatan dari usaha ternak sapi perah }\left(\mathrm{X}_{1.2}\right) \\
\text { 3. pendapatan dari usaha selain peternakan }\left(\mathrm{X}_{1.3}\right) \\
\text { 4. pendapatan dari usaha ternak lain }\left(\mathrm{X}_{1.4}\right) \\
\text { 5. pendapatan total untuk kebutuhan hidup }\left(\mathrm{X}_{1.5}\right) \\
\text { 6. jumlah tabungan }\left(\mathrm{X}_{1.6}\right) \\
\text { 7. jumlah hutang }\left(\mathrm{X}_{1.7}\right) \\
\text { 8. pelunasan hutang }\left(\mathrm{X}_{1.8}\right) \\
\text { 9. kepemilikan sapi pedet }\left(\mathrm{X}_{1.9}\right) \\
\text { 10. kepemilikan sapi dara }\left(\mathrm{X}_{1.10}\right) \\
\text { 11. kepemilikan sapi bunting }\left(\mathrm{X}_{1.11}\right) \\
\text { 12. kepemilikan sapi laktasi }\left(\mathrm{X}_{1.12}\right) \\
\text { 13. kepemilikan sapi periode kering }\left(\mathrm{X}_{1.13}\right) \\
\text { 14. jumlah populasi sapi yang dipelihara }\left(\mathrm{X}_{1.14}\right)\end{array}$ & $\begin{array}{l}\text { rupiah/tahun } \\
\text { rupiah/tahun } \\
\text { rupiah/tahun } \\
\text { rupiah/tahun } \\
\text { penerimaan - pengeluaran } \\
\text { rupiah/tahun } \\
\text { rupiah/tahun } \\
\text { hutang pokok - cicilan/ } \\
\text { bulan } \\
\text { ekor } \\
\text { ekor } \\
\text { ekor } \\
\text { ekor } \\
\text { ekor } \\
\text { ekor }\end{array}$ \\
\hline $\begin{array}{l}\text { Sumber daya } \\
\text { teknologi }\left(\mathrm{X}_{2}\right)\end{array}$ & $\begin{array}{l}\text { 1. } \text { pemilihan sapi indukan (bibit) }\left(\mathrm{X}_{2.1}\right) \\
\text { 2. } \text { teknologi pakan }\left(\mathrm{X}_{2.2}\right) \\
\text { 3. } \text { kesehatan ternak }\left(\mathrm{X}_{2.3}\right) \\
\text { 4. } \text { perkandangan }\left(\mathrm{X}_{2.4}\right) \\
\text { 5. } \text { pemasaran susu }\left(\mathrm{X}_{2.5}\right) \\
\text { 6. } \text { teknologi peningkatan produksi susu }\left(\mathrm{X}_{2.6}\right)\end{array}$ & $\begin{array}{l}\text { persentase keberhasilan } \\
\text { pemilihan bibit sapi } \\
\text { persentase pakan hasil } \\
\text { olahan sendiri } \\
\text { kondisi ternak sakit/tahun } \\
\text { status kepemilikan } \\
\text { persentase pengolahan } \\
\text { susu segar } \\
\text { adopsi teknologi/tahun }\end{array}$ \\
\hline $\begin{array}{l}\text { Sumber daya } \\
\text { fisik }\left(\mathrm{X}_{3}\right)\end{array}$ & $\begin{array}{ll}\text { 1. } & \text { rumah tempat tinggal }\left(\mathrm{X}_{3.1}\right) \\
\text { 2. } & \text { kandang sapi }\left(\mathrm{X}_{3.2}\right) \\
\text { 3. } & \text { sarana transportasi }\left(\mathrm{X}_{3.3}\right) \\
\text { 4. } & \text { sarana komunikasi }\left(\mathrm{X}_{3.4}\right) \\
\text { 5. } & \text { sarana informasi }\left(\mathrm{X}_{3.5}\right) \\
\text { 6. } & \text { penggunaan listrik }\left(\mathrm{X}_{3.6}\right) \\
\text { 7. } & \text { penguasaan lahan }\left(\mathrm{X}_{3.7}\right) \\
\text { 8. } & \text { pemanfaatan lahan }\left(\mathrm{X}_{3.8}\right) \\
\text { 9. } & \text { ketersediaan sumber air }\left(\mathrm{X}_{3.9}\right) \\
\text { 10. } & \text { ketersediaan sumber pakan }\left(\mathrm{X}_{3.10}\right) \\
\end{array}$ & $\begin{array}{l}\text { status kepemilikan } \\
\text { status kepemilikan } \\
\text { status kepemilikan } \\
\text { status kepemilikan } \\
\text { status kepemilikan } \\
\text { status kepemilikan } \\
\text { status kepemilikan } \\
\text { persentase pemanfaatan } \\
\text { lahan } \\
\text { jarak dan volume } \\
\text { jarak dan kg }\end{array}$ \\
\hline $\begin{array}{l}\text { SDM peternak } \\
\left(Z_{1}\right)\end{array}$ & $\begin{array}{l}\text { 1. } \text { pengetahuan dan keterampilan }\left(Z_{1.1}\right) \\
\text { 2. kesehatan }\left(Z_{1.2}\right) \\
\text { 3. motivasi }\left(Z_{1.3}\right) \\
\text { 4. } \\
\end{array}$ & $\begin{array}{l}\text { operasional usaha ternak } \\
\text { intensitas sakit/tahun } \\
\text { harapan peternak perihal } \\
\text { keberlanjutan usaha ternak } \\
\text { kemampuan peternak } \\
\text { berkomunikasi dengan } \\
\text { berbagai bahasa/tahun }\end{array}$ \\
\hline $\begin{array}{l}\text { Pengembangan } \\
\text { usaha }\left(\mathrm{Y}_{1}\right)\end{array}$ & $\begin{array}{ll}\text { 1. } & \text { peningkatan pendapatan }\left(\mathrm{Y}_{1.1}\right) \\
\text { 2. } & \text { peningkatan populasi ternak }\left(\mathrm{Y}_{1.2}\right) \\
\text { 3. } & \text { penambahan tenaga kerja }\left(\mathrm{Y}_{1.3}\right) \\
\text { 4. } & \text { penambahan kandang }\left(\mathrm{Y}_{1.4}\right) \\
\end{array}$ & $\begin{array}{l}\text { rupiah/tahun } \\
\text { ekor/tahun } \\
\text { orang/tahun } \\
\text { unit kandang/tahun } \\
\end{array}$ \\
\hline
\end{tabular}


modal atau aset keuangan (Amam et al., 2019a). Hasil uji indikator terhadap sumber daya finansial dengan menggunakan PLS (Partial Least Square) menghasilkan nilai outer loading yang ditampilkan pada Tabel 2.

Hasil uji indikator sumber daya finansial didapatkan delapan indikator yang memenuhi syarat dan dinyatakan valid. Syarat indikator yang dinyatakan valid adalah memiliki nilai outer loading minimal 0,500 . Hal tersebut menunjukkan bahwa sumber daya finansial usaha ternak sapi perah terdiri dari pendapatan utama, pendapatan total untuk kebutuhan hidup, kepemilikan sapi pedet, kepemilikan sapi dara, kepemilikan sapi bunting, kepemilikan sapi laktasi, kepemilikan sapi periode kering, dan jumlah populasi sapi yang dipelihara. Amam et al. $\left(2019^{b}\right)$ menyatakan bahwa sumber daya finansial berpengaruh secara positif terhadap dinamika kelompok peternak sapi perah.

\section{Sumber Daya Teknologi}

Sumber daya teknologi merupakan sumber daya yang berhubungan dengan adopsi, inovasi, dan implikasi pemanfataan teknologi (Amam et al., 2019a). Hasil uji indikator terhadap sumber daya teknologi dengan menggunakan PLS (Partial Least Square) menghasilkan nilai outer loading yang ditampilkan pada Tabel 3 .

Hasil uji indikator sumber daya teknologi didapatkan empat indikator yang memenuhi syarat dan dinyatakan valid. Indikator yang memenuhi syarat ialah indikator yang mempunyai nilai outer loading $>0,500$. Hal tersebut menunjukkan bahwa sumber daya fisik usaha ternak sapi perah terdiri dari pemilihan sapi indukan (bibit), teknologi pakan, perkandangan, dan teknologi peningkatan produksi susu. Amam et al. (2019b) menyatakan bahwa dinamika kelembagaan peternak sapi perah dipengaruhi oleh aksesibilitas peternak terhadap sumber daya fisik.

\section{Sumber Daya Fisik}

Sumber daya fisik merupakan sumber daya yang berhubungan dengan sarana dan prasarana yang mendukung usaha ternak (Amam et al., 2019a). Hasil uji indikator terhadap sumber daya fisik dengan menggunakan PLS (Partial Least Square) menghasilkan nilai outer loading yang ditampilkan pada Tabel 4.

Hasil dari pengujian indikator sumber daya fisik terdapat tiga yang valid dan memenuhi syarat. Dinyatakan valid dan memenuhi syarat ialah indkator yang mempunyai nilai outer loading $>0,500$. Hal tersebut menunjukkan bahwa sumber daya teknologi usaha ternak sapi perah terdiri dari sarana transportasi, penguasaan lahan, dan ketersediaan sumber pakan. Amam et al. (2019b) menyatakan bahwa sumber daya fisik memberikan pengaruh terhadap dinamika

Tabel 2. Indikator sumber daya finansial

\begin{tabular}{lccc}
\hline Indikator & Notasi & Outer Loading & Keterangan \\
\hline Pendapatan utama & $\mathrm{X}_{1.1}$ & 0,716 & valid \\
Pendapatan total untuk kebutuhan hidup & $\mathrm{X}_{1.5}$ & 0,645 & valid \\
Kepemilikan sapi pedet & $\mathrm{X}_{1.9}$ & 0,617 & valid \\
Kepemilikan sapi dara & $\mathrm{X}_{1.10}$ & 0,651 & valid \\
Kepemilikan sapi bunting & $\mathrm{X}_{1.11}$ & 0,860 & valid \\
Kepemilikan sapi laktasi & $\mathrm{X}_{1.12}$ & 0,728 & valid \\
Kepemilikan sapi periode kering & $\mathrm{X}_{1.13}$ & 0,740 & valid \\
Jumlah populasi sapi yang dipelihara & $\mathrm{X}_{1.14}$ & 0,842 & valid \\
\hline
\end{tabular}

Keterangan: Nilai Outer Loading setelah menghilangkan indikator tidak valid (Sumber: Output PLS, 2019) 
Tabel 3. Indikator sumber daya teknologi

\begin{tabular}{lccc}
\hline Indikator & Notasi & Outer Loading & Keterangan \\
\hline Pemilihan sapi indukan (bibit) & $\mathrm{X}_{2.1}$ & 0,718 & valid \\
Teknologi pakan & $\mathrm{X}_{2.2}$ & 0,554 & valid \\
Perkandangan & $\mathrm{X}_{2.4}$ & 0,626 & valid \\
Teknologi peningkatan produksi susu & $\mathrm{X}_{2.6}$ & 0,743 & valid \\
\hline
\end{tabular}

Keterangan: Nilai Outer Loading setelah menghilangkan indikator tidak valid (Sumber: Output PLS, 2019)

Tabel 4. Indikator sumber daya fisik

\begin{tabular}{lccc}
\hline Indikator & Notasi & Outer Loading & Keterangan \\
\hline Sarana transportasi & $\mathrm{X}_{3.3}$ & 0,822 & valid \\
Penguasaan lahan & $\mathrm{X}_{3.6}$ & 0,694 & valid \\
Ketersediaan sumber pakan & $\mathrm{X}_{3.10}$ & 0,592 & valid \\
\hline
\end{tabular}

Keterangan: Nilai Outer Loading setelah menghilangkan indikator tidak valid (Sumber: Output PLS, 2019)

kelompok peternak sapi perah.

\section{Sumber Daya Manusia}

Sumber Daya Manusia (SDM) peternak adalah individu penggerak usaha ternak. Hasil uji indikator terhadap sumber daya manusia dengan menggunakan PLS (Partial Least Square) menghasilkan nilai outer loading yang ditampilkan pada Tabel 5 .

Hasil uji indikator Sumber Daya Manusia (SDM) didapatkan dua indikator yang memenuhi syarat dan dinyatakan valid. Indikator valid sesuai persyaratan uji outer model di dalam metode PLS memiliki nilai outer loading $>0,500$. Hal tersebut menunjukkan bahwa SDM peternak sapi perah terdiri dari pengetahuan dan keterampilan serta penguasaan bahasa seharihari. Amam dan Harsita (2019a) menyatakan bahwa pengembangan usaha ternak dapat mempengaruhi SDM peternak.

\section{Pengembangan Usaha Ternak}

Pengembangan usaha ternak merupakan suatu proses menghasilkan output (barang dan/atau jasa) di bidang peternakan untuk pemenuhan kebutuhan masyarakat, sehingga saat terjadi peningkatan kebutuhan maka peternak meningkatkan nilai investasi yang semata-mata bertujuan untuk meningkatkan keuntungan (profitabilitas). Hasil uji indikator terhadap pengembangan usaha ternak dengan menggunakan PLS (Partial Least Square) menghasilkan nilai outer loading yang ditampilkan pada Tabel 6.

Hasil uji indikator pengembangan usaha ternak didapatkan dua indikator yang memenuhi syarat dan dinyatakan valid. Indikator yang memenuhi syarat ialah indikator yang mempunyai nilai outer loading $>0,500$. Hal tersebut menunjukkan bahwapengembangan usaha ternak terdiri daripeningkatan pendapatan dan peningkatan populasi ternak. Amam et al. (2019a) menyatakan bahwa pengembangan usaha ternak sapi perah dipengaruhi oleh sumber daya eksternal dan SDM peternak sapi perah.

\section{Uji Struktural}

Pengujian terhadap indikator secara serempak dengan menggunakan PLS (Partial Least Square) menghasilkan nilai kriteria yang terdiri dari Nilai Average Variance Extracted (AVE), nilai Composite Reliability (CR), nilai Cronbach's Alpha (CA), dan nilai $R$ Square $\left(\mathrm{R}^{2}\right)$. Hasil uji tersebut menghasilkan nilai kriteria pada Tabel 7 dan Gambar 1.

\section{Uji Model}

Pengujian terhadap hubungan pengaruh 
JPI Vol. 22 (1): 1-10

Tabel 5. Indikator sumber daya manusia

\begin{tabular}{lccc}
\hline Indikator & Notasi & Outer Loading & Keterangan \\
\hline Pengetahuan dan keterampilan & $\mathrm{Z}_{1,1}$ & 0,849 & valid \\
Penguasaan bahasa sehari-hari & $\mathrm{Z}_{1,4}$ & 0,715 & valid \\
\hline
\end{tabular}

Keterangan: Nilai Outer Loading setelah menghilangkan indikator tidak valid (Sumber: Output PLS, 2019)

Tabel 6. Indikator pengembangan usaha ternak

\begin{tabular}{lccc}
\hline Indikator & Notasi & Outer Loading & Keterangan \\
\hline Peningkatan pendapatan & $\mathrm{Y}_{1,1}$ & 0,866 & valid \\
Peningkatan populasi ternak & $\mathrm{Y}_{1,2}$ & 0,895 & valid \\
\hline
\end{tabular}

Keterangan: Nilai Outer Loading setelah menghilangkan indikator tidak valid (Sumber: Output PLS, 2019)

Tabel 7. Uji Kriteria PLS

\begin{tabular}{lcccc}
\hline Variabel & AVE & CR & CA & $\mathrm{R}^{2}$ \\
\hline $\mathrm{X}_{1}$ & 0,632 & 0,899 & 0,971 & \\
$\mathrm{X}_{2}$ & 0,641 & 0,757 & 0,874 & \\
$\mathrm{X}_{3}$ & 0,602 & 0,748 & 0,820 & \\
$\mathrm{Z}_{1}$ & 0,715 & 0,760 & 0,783 & 0,188 \\
$\mathrm{Y}_{1}$ & 0,875 & 0,873 & 0,912 & 0,555 \\
\hline
\end{tabular}

Sumber: Output PLS (2019)

dilakukan setelah uji indikator dengan mengeliminasi indikator yang tidak valid dan tidak memenuhi syarat, yaitu mempunyai nilai outer loading $<0,500$. Uji pengaruh meliputi nilai koefisien parameter, nilai t-statistik, dan nilai koefisien determinasi $\left(\mathrm{R}^{2}\right)$. Hasil pengujian tersebut ditunjukkan pada Tabel 8 .

Pengaruh Sumber Daya Internal Usaha Ternak Sapi Perah terhadap SDM Peternak

Peternak sapi perah di Kelompok Usaha Bersama (KUB) Tirtasari Kresna Gemilang memiliki aksesibilitas sumber daya finansial, teknologi, dan fisik. Sumber daya internal mempengaruhi SDM (Sumber Daya Manusia) peternak sapi perah sebesar $18,9 \%$. Hal tersebut mengindikasikan bahwa aksesibilitas sumber daya yang dimiliki peternak dapat mempengaruhi tinggi dan rendahnya Sumber Daya Manusia (SDM) peternak. Sumber Daya Manusia (SDM) peternak adalah individu penggerak usaha ternak (Amam dan Harsita, 2019a). Amam et al. (2019c) mengemukkaan bahwa sumber daya dapat berpengaruh terhadap kualitas SDM peternak, dan juga dapat mempengaruhi pengembangan usaha ternak (Amam et al., 2019d).

Sumber daya finansial memberikan pengaruh terhadap SDM peternak sapi perah. Pengaruh tersebut memperlihatkan hasil negatif sebesar $-0,042$. Artinya, semakin kecil sumber daya finansial yang dapat diakses peternak sapi perah maka semakin tinggi SDM peternak. Hal tersebut menunjukkan bahwa peternak yang memiliki keterbatasan sumber daya finansial di KUB Tirtasari Kresna Gemilang mempunyai SDM yang tinggi. Contoh di lokasi penelitian ialah ketika peternak mempunyai sumber daya finansial yang terbatas, maka peternak cenderung memiliki pengetahuan dan keterampilan yang lebih tinggi jika dibandingkan peternak yang mempunyai akses lebih banyak 
JPI Vol. 22 (1): 1-10

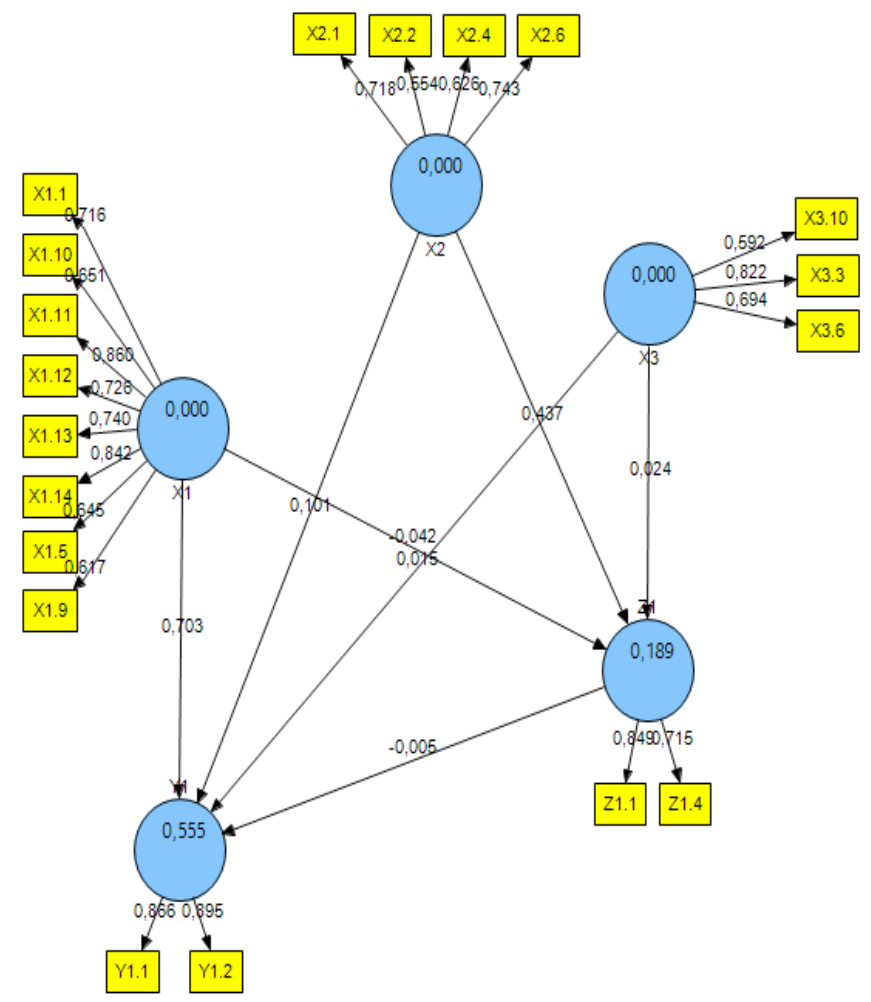

Gambar 1. Hasil logaritma PLS

terhadap sumber daya finansial, sebab dengan keterbatasan finansial peternak sapi perah lebih cenderung mengerjakan usaha ternaknya secara mandiri dan semaksimal mungkin untuk menunjang kebutuhan hidup. Riszqina et al. (2014) dan Asmara et al. (2017) menyebutkan bahwa skala usaha berpengaruh nyata terhadap produktivitas ternak.

Sumber daya teknologi memberikan pengaruh terhadap SDM peternak sapi perah. Pengaruh tersebut memperlihatkan hasil positif signifikan sebesar 0,437 dengan nilai $t$ statistik 4,886. Artinya, semakin besar sumber daya teknologi yang dapat diakses peternak sapi perah maka semakin tinggi SDM peternak. Hal tersebut menunjukkan bahwa peternak yang memiliki akses terhadap sumber daya teknologi di KUB Tirtasari Kresna Gemilang mempunyai SDM yang tinggi. Contoh di lokasi penelitian ialah ketika peternak sapi perah dan menggunakan teknologi dalam pemilihan bibit sapi perah (indukan) berarti peternak memiliki pengetahuan dan keterampilan dalam usaha ternak sapi perah. Perilla et al. (2009) menyebutkan bahwa melakukan pembibitan sendiri merupakan langkah awal untuk memulai investasi.

Sumberdayafisikmemberikanpengaruh terhadap SDM peternak sapi perah. Pengaruh tersebut memperlihatkan hasil positif sebesar 0,024 . Artinya, semakin besar sumber daya fisik yang dapat diakses peternak sapi perah maka semakin tinggi SDM peternak. Hal tersebut menunjukkan bahwa peternak yang memiliki akses terhadap sumber daya fisik di KUB Tirtasari Kresna Gemilang mempunyai SDM yang tinggi. Contoh di lokasi penelitian ialah ketika peternak sapi perah memiliki sarana transportasi, penguasaan lahan, dan ketersediaan sumber pakan maka terdapat peningkatan pengetahuan dan keterampilan peternak untuk melakukan integrasi tanaman 
JPI Vol. 22 (1): 1-10

Tabel 8. Uji model

\begin{tabular}{|c|c|c|}
\hline Pengujian & Hasil Uji & Result \\
\hline $\begin{array}{l}\text { Koefisien Determinasi } \mathrm{R}^{2} \\
\text { SDM Peternak Sapi Perah } \\
\text { Pengembangan Usaha Ternak Sapi Perah }\end{array}$ & $\begin{array}{l}0,189 \\
0,555\end{array}$ & \\
\hline $\begin{array}{l}\frac{\text { t-statitstik }}{X_{1} \rightarrow Z_{1}} \\
X_{2} \rightarrow Z_{1} \\
X_{3} \rightarrow Z_{1} \\
X_{1} \rightarrow Y_{1} \\
X_{2} \rightarrow Y_{1} \\
X_{3} \rightarrow Y_{1} \\
Z_{1} \rightarrow Y_{1}\end{array}$ & $\begin{array}{c}2,287 \\
4,886 \\
3,141 \\
10,069 \\
3,332 \\
2,182 \\
2,069 \\
\end{array}$ & $\begin{array}{l}\text { signifikan } \\
\text { signifikan } \\
\text { signifikan } \\
\text { signifikan } \\
\text { signifikan } \\
\text { signifikan } \\
\text { signifikan }\end{array}$ \\
\hline $\begin{array}{l}\text { Koefisien Parameter } \\
X_{1} \rightarrow Z_{1} \\
X_{2} \rightarrow Z_{1} \\
X_{3} \rightarrow Z_{1} \\
X_{1} \rightarrow Y_{1} \\
X_{2} \rightarrow Y_{1} \\
X_{3} \rightarrow Y_{1} \\
Z_{1} \rightarrow Y_{1}\end{array}$ & $\begin{array}{c}-0,042 \\
0,437 \\
0,024 \\
0,703 \\
0,101 \\
0,015 \\
-0,005 \\
\end{array}$ & $\begin{array}{l}\text { negatif } \\
\text { positif } \\
\text { positif } \\
\text { positif } \\
\text { positif } \\
\text { positif } \\
\text { negatif }\end{array}$ \\
\hline
\end{tabular}

Sumber: Data diolah (2019)

dengan ternak. Tawaf et al. (2016) sistem integrasi tanaman dengan ternak dapat meningkatkan penerimaan dan pendapatan peternak.

\section{Pengaruh Sumber Daya Internal Usaha Ternak Sapi Perah terhadap Pengembangan Usaha}

Sumber daya internal usaha ternak sapi perah di Kelompok Usaha Bersama (KUB) Tirtasari Kresna Gemilang terdiri dari sumber daya finansial, sumber daya teknologi, dan sumber daya fisik. Sumber daya internal mempengaruhi pengembangan usaha ternak sapi perah sebesar 55,5\%. Pengembangan usaha ternak sapi perah berpengaruh terhadap SDM peternak (Amam dan Harsita, 2019a). Amam dan Harsita (2019) menyebutkan bahwa pengembangan usaha ternak juga dipengaruhi secara positif dan signikan oleh performa kelembagaan.

Sumber daya finansial memberikan pengaruh terhadap pengembangan usaha ternak sapi perah melalui SDM peternak.
Pengaruh tersebut memperlihatkan hasil positif sebesar 0.703, sedangkan semakin tinggi SDM peternak maka semakin rendah upaya pengembangan usaha yang dilakukan oleh peternak. Di sisi lain, skala usaha ternak sangat berpengaruh terhadap produktivitas ternak (Riszqina et al., 2014), sedangkan produktivitas dan profitabilitas usaha ternak dengan skala besar lebih tinggi jika dibandingkan usaha ternak dengan skala kecil (Asmara et al., 2017).

Sumber daya teknologi memberikan pengaruh terhadap pengembangan usaha ternak sapi perah melalui SDM peternak. Pengaruh tersebut memperlihatkan hasil positif sebesar 0,101, sedangkan semakin tinggi SDM peternak maka semakin rendah upaya pengembangan usaha yang dilakukan oleh peternak. Contoh di lokasi penelitian ialah ketika peternak melakukan pembibitan sendiri dengan Inseminasi Buatan (IB) atau kawin suntik maka harapannya penambahan populasi ternak sapi perah semakin cepat. 
Nurdin dan Andri (2012) menyebutkan bahwa salah satu ancaman dalam melakukan pembibitan sapi perah ialah persaingan dengan industri pembibitan sapi perah multinasional.

Sumber daya fisik memberikan pengaruh terhadap pengembangan usaha ternak sapi perah melalui SDM peternak. Pengaruh tersebut memperlihatkan hasil positif sebesar 0,015, sedangkan semakin tinggi SDM peternak maka semakin rendah upaya pengembangan usaha yang dilakukan oleh peternak. Contoh di lokasi penelitian ialah ketika peternak melakukan integrasi tanaman dengan ternak maka penerimaan dan pendapatan peternak semakin tinggi. Hal tersebut karena tantangan pertanian di masa yang akan datang semakin kompleks, sehingga dibutuhkan sinergi antara teknologi dan inovasi, juga penyempurnaan kebijakan serta penguatan kelembagaan (Hermanto, 2018).

\section{KESIMPULAN}

Sumber daya internal mempengaruhi SDM peternak sapi perah sebesar $18,9 \%$. Pengembangan usaha ternak sapi perah dipengaruhi oleh sumber daya internal dan SDM peternak sebesar 55,5\%.

Indikator pembentuk sumber daya finansial ialah pendapatan utama, pendapatan total untuk kebutuhan hidup, kepemilikan sapi pedet, kepemilikan sapi dara, kepemilikan sapi bunting, kepemilikan sapi laktasi, kepemilikan sapi periode kering, dan jumlah populasi sapi yang dipelihara. Indikator pembentuk sumber daya teknologi ialah pemilihan sapi indukan (bibit), teknologi pakan, perkandangan, dan teknologi peningkatan produksi susu. Indikator pembentuk sumber daya fisik ialah sarana transportasi, penguasaan lahan, dan ketersediaan sumber pakan.

\section{UCAPAN TERIMA KASIH}

Naskah jurnal ini merupakan bagian dari luaran penelitian dengan menggunakan dana DIPA Universitas Jember Tahun Anggaran 2019. Banyak pihak yang terlibat di dalam penelitian ini hingga naskah jurnal ini terbit. Ucapan terimakasih penulis sampaikan kepada: 1) Lembaga Penelitian dan Pengabdian kepada Masyarakat (LP2M) Universitas Jember (UNEJ), 2) Kelembagaan Peternak Sapi Perah "Kelompok Usaha Bersama" (KUB) Tirtasari Kresna Gemilang, 3) Kelompok Riset (KeRis) IFSLR (Integrated Farming System for Large Ruminant) untuk pengembangan komoditas ternak ruminansia besar, 4) Kelompok Riset (KeRis) Socioeconomic Aspects of Livestock Farming and Product Technology (SOSEK-THT), dan 5) Program Studi Peternakan Fakultas Pertanian Universitas Jember.

\section{DAFTAR PUSTAKA}

Amam dan Harsita, P. A. 2019 . Efek Domino Performa Kelembagaan, Aspek Risiko, dan Pengembangan Usaha terhadap SDM Peternak Sapi Perah. Sains Peternakan. 17 (1): 5-11.

Amam dan Harsita. P. A. 2019 . Aspek Kerentanan Usaha Ternak Sapi Perah di Kabupaten Malang. Agrimor: Jurnal Agribisnis Lahan Kering. 4 (2): 26-28.

Amam dan Soetriono. 2019. Evaluasi Performa Kelembagaan Peternak Sapi Perah Berdasarkan Aspek Risiko Bisnis dan Pengembangan Usaha. Jurnal Ilmu dan Teknologi Peternakan Tropis. 6 (1): 8-13.

Amam, Jadmiko, M. W., Harsita, P. A., dan Poerwoko, M. S. 2019a. Model Pengembangan Usaha Ternak Sapi Perah. Jurnal Sain Peternakan Indonesia. 14 (1): 61-69.

Amam, Jadmiko, M. W., Harsita, P. A., Widodo, N., dan Poerwoko, M. S.

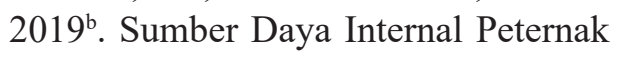
Sapi Perah dan Pengaruhnya terhadap Dinamika Kelompok dan Konteks Kerentanan. Jurnal Ilmiah Peternakan Terpadu. 7 (1): 192-200. 
Amam, Zaenal, F., Hartono, B., dan Nugroho, B. A. $2019^{c}$. Identification of Resources in the System of Broiler Farming Business. Indonesia Journal of Animal dan Veterinary Science. 24 (3): 1-8.

Amam, Zaenal, F., Hartono, B., dan Nugroho, B. A. 2019d. Usaha Ternak Ayam Pedaging Sistem Kemitraan Pola Dagang Umum: Pemetaan Sumber Daya dan Model Pengembangan. Sains Peternakan. 17 (2): 5-11.

Asmara, A., Purnamadewi, Y. L., and Lubis, D. 2017. The Relationship Analysis between Service Performances of Milk Producer Cooperative with the Dairy Farm Performance of Members. Media Peternakan. 40 (2): 143-150.

Hermanto. 2018. Pengentasan Kemiskinan di Perdesaan: Pengembangan SDM, Penguatan Usaha, dan Inovasi Pertanian. Forum Penelitian Agro Ekonomi. 35 (2): 139-150.

Nasrul, W. 2012. Pengembangan Kelembagaan Pertanian untuk Meningkatkan Kapasitas Petani terhadap Pembangunan Pertanian. Jurnal Menara Ilmu 3(29): 166-174.

Nurdin, E. dan Andri. 2012. Usaha Pembibitan Sapi Perah di Universitas Andalas. Jurnal Peternak Indonesia. 14 (2): 355359.
Perilla, M. V., Escala, J. M., and Setiadi, A. 2009. A Case Study of Luntian Multipurpose Cooperative in Barangay Lalaig, Tiaong, Quezon, Philippines: A Vertical Integration Approach. JITAA. 34 (3): 216-223.

Riszqina, Isbandi, Rianto, E., and Santoso, S. I. 2014. The Analysis of Factors Affecting The Performance in Benefits of Karapan (Racing) Cattle Business in Madura Island, East Java. JITAA. 39 (1): 65-72.

Syukur, S. H., Fanani, Z., Nugroho, B. A., and Antara, M. 2014. Empowerment of Livestock Farmer through Graduate Program to Build a Village on Dynamics of Beef Cattle Farmer Groups Level of Gaduhan Model (A Case Study in the District of Toli-toli, Central Sulawesi. Journal of Natural Science Research. 4 (2): 107-112.

Tawaf, R., Paturochman, M., Herlina, R., Sulistiyati, M., and Fitriani, A. 2016. The Optimation of Farmers Familities Revenue The Integration of Pasundan Cattle and Paddy Farming in West Java. JITAA. 42 (4): 270-278.

Wiyono, G. 2011. Merancang Penelitian Bisnis dengan Alat Analisis SPSS 17.0 \& Smart PLS 2.0. Penerbit: Unit Penerbit dan Percetakan STIM YKPN Yogyakarta. Yogyakarta. 